\title{
Management of prolonged hypoglycaemia in Beckwith's syndrome
}

\author{
M. W. MONCRIEFF* \\ B.M., B.Ch., M.R.C.P.
}

\author{
K. A. LACEY \\ M.B., Ch.B., M.R.C.P.
}

\author{
P. N. Malleson \\ M.B., B.S., M.R.C.P.
}

Special Care Baby Unit and Derbyshire Children's Hospital

\begin{abstract}
Summary
A new-born baby with Beckwith's syndrome had severe hypoglycaemia, and was treated with glucagon and prednisone. Treatment was stopped at 1 month of age and his blood glucose levels were satisfactory for the ensuing 6 weeks. However, at 10 weeks of age, he had a hypoglycaemic convulsion and required large doses of diazoxide and prednisone for the next 2 months to maintain the blood glucose above 40 $\mathrm{mg} / \mathbf{1 0 0} \mathrm{ml}$. Insulin excretion was raised until he was 4 months old. Cases of Beckwith's syndrome which develop hypoglycaemia, should be treated with diazoxide and corticosteroids until insulin excretion is normal.
\end{abstract}

\section{Introduction}

Hypoglycaemia occurs in $30-50 \%$ of babies with Beckwith's syndrome, usually responds readily to treatment with corticosteroids and generally lasts less than 4 months (Beckwith, 1969). Hypoglycaemia may occasionally be severe and prolonged when treatment becomes difficult. This includes frequent small feeds, glucagon, diazoxide, corticosteroids and epinephrine alone or in various combinations (Beckwith et al., 1964; Combs, Grunt and Brandt, 1966; Mariani et al., 1969; Schiff et al., 1973; Gotlin, 1973) and in one very severe case, partial pancreatectomy on the twenty-fourth day of life (Roe et al., 1973).

The management of an infant, with Beckwith's syndrome, who had severe hypoglycaemia for 4 months, is now described.

\section{Case report}

After a pregnancy complicated by hydramnios and pre-eclamptic toxaemia, a boy was born by a normal delivery at 37 weeks' gestation, and weighed $3.2 \mathrm{~kg}$ (above the 90th centile).

Beckwith's syndrome was diagnosed after finding a very large tongue, linear indentations across the

\footnotetext{
* Present address: Radcliffe Infirmary, Oxford.
}

TABLE 1. Investigations in first few days of life

\begin{tabular}{llccc}
\hline \multicolumn{1}{c}{ Age } & $3 \mathrm{hr}$ & 2 days & 3 days & 6 days \\
\hline Glucose $(\mathrm{mg} / 100 \mathrm{ml})$ & 22 & 26 & $<25$ & 45 \\
Insulin $(\mu \mathrm{u} / \mathrm{ml})$ & 37 & 51 & 36 & 29 \\
Hb $(\mathrm{g} / 100 \mathrm{ml})$ & 25 & & & \\
PCV & 57 & & & \\
Calcium $(\mathrm{mg} / 100 \mathrm{ml})$ & & 5.4 & 4.6 & 8.0 \\
Cortisol $(\mu \mathrm{g} / 100 \mathrm{ml})$ & 19.5 & & & \\
\hline
\end{tabular}

pinna of both ears, and enlarged kidneys and liver; investigations shortly after birth (Table 1) showed hypoglycaemia and hyperinsulinism, for which he was treated with $10 \%$ dextrose intravenously, and 3hourly milk feeds. Frequent dextrostix readings were greater than $25 \mathrm{mg} / 100 \mathrm{ml}$, until $60 \mathrm{hr}$ of age. He then had a series of convulsions associated with a blood glucose level below $25 \mathrm{mg} / 100 \mathrm{ml}$. After $50 \%$ dextrose i.v. and glucagon $0.5 \mathrm{mg}$, and prednisone 1 $\mathrm{mg}$, each three times a day, convulsion ceased and the blood glucose levels remained over $40 \mathrm{mg} / 100 \mathrm{ml}$. He developed hypocalcaemia (serum calcium 5.4 $\mathrm{mg} / 100 \mathrm{ml}$ ) which was treated with i.v. calcium gluconate, and hyperbilirubinaemia (plasma bilirubin $19 \mathrm{mg} / 100 \mathrm{ml}$ ) requiring phototherapy. Initially he had marked neck retraction and was unresponsive after the convulsions, but by 1 week of age he was completely bottle feed, had normal muscle tone and a normal Moro reflex. His blood glucose levels remained satisfactory, so that treatment was gradually withdrawn by 1 month of age when he was discharged home.

He remained asymptomatic until 10 weeks of age when he had a hypoglycaemic convulsion (dextrostix $<25 \mathrm{mg} / 100 \mathrm{ml}$ ). He was treated with i.v. dextrose, diazoxide $50 \mathrm{mg}$, and later $75 \mathrm{mg}$, daily, and prednisone $5 \mathrm{mg}$ increased to $10 \mathrm{mg}$ daily. The blood glucose was frequently below $40 \mathrm{mg} / 100 \mathrm{ml}$ during the next 3 weeks; the lowest level each day in relation to treatment is shown in Fig. 1. Serum insulin levels remained elevated until he was 3.5 months of age (Table 2). 


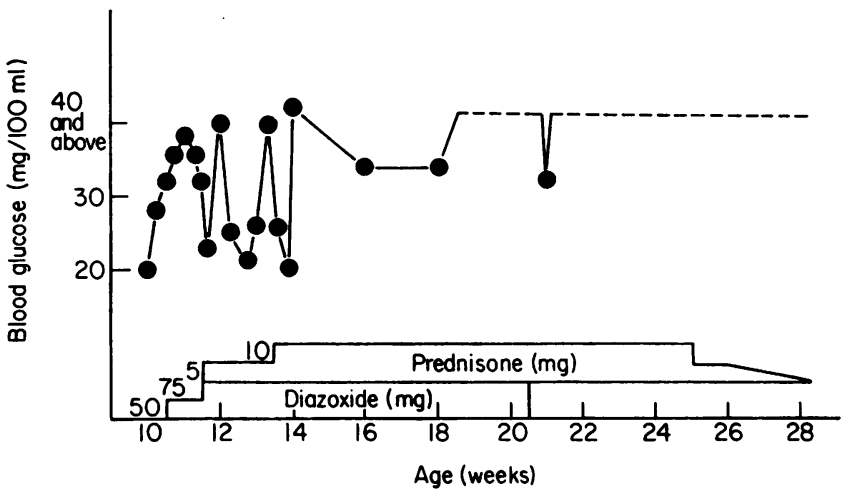

Fig. 1. Blood glucose level related to treatment. - Lowest of daily measurements; -- -, over $40 \mathrm{mg} / 100 \mathrm{ml}$.

TABLE 2. Blood glucose and insulin levels before and after feeds at various ages, related to treatment

\begin{tabular}{lccccc}
\hline \multicolumn{7}{c}{ Age (weeks) } \\
\cline { 2 - 6 } & 10 & 14 & 17 & 22 & 28 \\
\hline Time (min) & $0-60-120$ & 0 & $0-60-120$ & $0-60-120$ & $0-60-120$ \\
$\begin{array}{l}\text { Glucose } \\
(\mathrm{mg} / 100 \mathrm{ml})\end{array}$ & 207040 & 42 & 608974 & 646062 & 556061 \\
$\begin{array}{l}\text { Insulin } \\
(\mu \mathrm{u} / \mathrm{ml})\end{array}$ & 201820 & 16 & 61010 & 131212 & 10149 \\
$\begin{array}{l}\text { Treatment } \\
\text { Nil }\end{array}$ & Nil & $\begin{array}{c}\text { Prednisone } \\
\text { Diazoxide }\end{array}$ & $\begin{array}{c}\text { Prednisone } \\
\text { Diazoxide }\end{array}$ & $\begin{array}{c}\text { Predisone } \\
\text { Diazoxide }\end{array}$ & Nil \\
\hline
\end{tabular}

When 20 weeks old, he had two episodes of diarrhoea and vomiting for which it was thought that diazoxide might be partially responsible so it was discontinued. Serum insulin levels remained normal, and after a synacthen test had shown a satisfactory rise in plasma cortisol, prednisone was gradually withdrawn. Two weeks later blood glucose, serum insulin and cortisol levels were normal. Psychomotor development at 8 months was within the normal range.

\section{Discussion}

The severe prolonged hypoglycaemia in this case of Beckwith's syndrome may be fatal or cause mental retardation (Beckwith, 1969), and illustrates some of the problems of management. The hypoglycaemia was due to excessive insulin secretion which has previously been demonstrated in only six cases (Beckwith et al., 1964; Combs et al., 1966; Mariani et al., 1969; Schiff et al., 1973; Gotlin, 1973). Treatment of these cases has been difficult and has consisted of intravenous and oral glucose, diazoxide, corticosteroids, glucagon, and epinephrine, alone, or in various combinations. However, side effects of these drugs may limit their usefulness.
This case required $15 \mathrm{mg} / \mathrm{kg}$ diazoxide which isp considerably more than the $10 \mathrm{mg} / \mathrm{kg}$ used by Schiff. et al. (1973), but similar to the dose used by Gotling (1973). Diazoxide was stopped in this patient when the serum insulin level was normal, as it was though it might be contributing to his diarrhoea, but therê was no evidence of bone marrow suppression as? occurred in one of the cases reported by Combs $e \vec{b}$. al. (1966). Corticosteroids and glucagon were found by these authors to be effective in raising the blood sugar. However, in the case reported by Schiff et al (1973), glucagon caused an increase in insulino secretion and they concluded that it could exacerbate hypoglycaemia. It has to be given by i.m. injectiono which limits its usefulness in prolonged cases. For the same reason, epinephine, as recommended by Schiff et al. (1973) is not practical for prolonged therapy. Intravenous and oral glucose, without hyperglycaemic drugs, are not sufficient to maintaing the blood glucose as this case shows.

Although the diagnosis of Beckwith's syndrome was made a few minutes after birth, and hypoglycaes mia anticipated and treated vigorously, the infant had two short periods of symptomatic hypoglycae$\mathrm{mia}$. The first, at the age of 2 days was due to relying 
on oral and intravenous glucose alone to maintain the blood glucose level, and the second was at the age of 10 weeks. Treatment had been stopped gradually by the age of 1 month as the infant's blood glucose was satisfactory, but the insulin levels had not returned to normal.

In future cases, treatment should include diazoxide and corticosteroids as soon as the diagnosis of hypoglycaemia is made. These drugs should be withdrawn slowly when the blood glucose level is satisfactory and the serum insulin levels are normal.

\section{References}

BeCKWITH, J.B. (1969) Macroglossia, omphalocele, adrenal cytomegaly, gigantism and hyperplastic visceromegaly. Birth Defects: Original Article Series, 5, 188.

Beckwith, J.B., WaNG, C., DonNell, G.N. \& GwinN, J.L. (1964) Hyperplastic fetal visceromegaly with macroglossia, omphalocele, cytomegaly of adrenal fetal cortex, postnatal somatic gigantism, and other abnormalities: newly recognized syndrome. Proceedings of the American Pediatric Society, June (16-18) (Abst. No. 41).

Combs, J.T., GrunT, J.A. \& BRANDT, I.K. (1966) New syndrome of neonatal hypoglycaemia; association with visceromegaly, macroglossia, microcephaly, and abnormal umbilicus. New England Journal of Medicine, 275, 236.

GotLIN, R.W. (1973) Diazoxide therapy in the syndrome of Beckwith-Weidemann-Coombs. Journal of Pediatrics, 83, 342.

Mariani, R., Unal, D., Spriet, A., Carcassonne, M. \& Bernard, R. (1969) Hypoglycémie du nouveau-né avec microcéphalie, macroglossie et mégalosplanchnie. Archives Françaises de Pédiatrie, 26, 337.

Roe, T.F., Kershnar, A.K., Weitzman, J.J. \& Madrigal, L.S. (1973) Beckwith's syndrome with extreme organ hyperplasia. Pediatrics, 52, 372.

Schiff, D., Colle, E., Wells, D. \& Stern, L. (1973) Metabolic aspects of the Beckwith-Weidemann syndrome. Journal of Pediatrics, 82, 258.

\title{
Lactate production in McArdle's disease
}

\author{
A. K. BAKSI* \\ M.B., B.S., M.R.C.P. \\ P. H. BuXTON $\dagger$ \\ M.D., F.R.C.P., F.R.C.Path. \\ P. COCHRANE + \\ M.D., M.R.C.P. \\ R. R. HugheS \\ M.D., F.R.C.P. \\ *Liverpool Royal Infirmary, $\nmid$ Regional Centre for Medical and Surgical Neurology, \\ Liverpool, $\ddagger$ Stoke Mandeville Hospital, Aylesbury, and §Royal Southern Hospital, Liverpool
}

\begin{abstract}
Summary
A case of McArdle's disease in a man is described in detail and a less complete study of his family is reported. This patient showed the classical features of McArdle's disease and the diagnosis was confirmed by muscle biopsy. Unlike other reported cases of this disorder, this case showed a normal rise in blood lactate levels on ischaemic exercise. This apparently paradoxical finding is discussed. It is suggested that a normal rise in the level of blood lactate on ischaemic exercise should not exclude myophosphorylase deficiency.
\end{abstract}

\section{Introduction}

In 1951, McArdle reported the case of a 30-year-

Correspondence: Dr A. K. Baksi, 11 Whitestone Road, Knowsley, Merseyside. old man who had suffered from life-long muscular pain on slight exertion, progressing on continued exertion to weakness and stiffness. These symptoms usually disappeared on resting. Localized swellings in muscle and abnormal shortening of flexor muscles were seen to occur after ischaemic exercise. Electromyography showed that muscle shortening was a reversible physiological contracture of the muscle fibre not associated with any conducted action potential in the muscle. An important finding was the absence of the normal rise in blood lactic acid on ischaemic exercise. Subsequently, further cases were reported by Pearson, Rimmer and Mommaerts (1959), Schmid and Mahler (1959), Mellick, Mahler and Hughes (1962) and Schmid and Hammaker (1961), and in all instances the blood lactic acid level failed to rise on ischaemic exercise. Histochemical study of muscles from these patients 